\title{
Resolving Water Conflicts: A Comparative Analysis of Interstate River Compacts
}

\author{
Edella Schlager, University of Arizona \\ and \\ Tanya Heikkila, Columbia University
}

\section{Accepted for Publication in Policy Studies Journal}

\begin{abstract}
This paper examines compacts used by U.S. western states to engage in shared governance of interstate rivers. Compacts are viewed as inflexible, rigid governance structures incapable of responding to changing environmental and institutional settings because of the use of unanimity rules and the inability to directly regulate water users. Using data from a study of 14 western interstate river compacts we examine this claim. In particular, we explore the response of compacts to water conflicts. We find that members of compacts, closely related water agencies, and compact governments are capable of responding to conflicts. To better understand this finding, we identify the conditions under which compacts are likely to address conflicts, as well as the types of conflict solutions compact governments adopted.
\end{abstract}

Keywords: conflict resolution; interstate compacts; institutional analysis and development framework; qualitative comparative analysis 
The past decade has witnessed considerable attention to collaborative efforts among independent parties who use consensus or unanimity rules to jointly plan for or govern a collective benefit. Collaborative efforts are well known in the field of water resource governance, where multiple actors and governments often share authority over a common resource (Heikkila and Gerlak 2005; Koontz et al 2004; Leach and Sabatier 2005; Lubell et. al. 2002; Sabatier et. al. 2005; Weber 2003). Examples range from local watershed councils, to multi-state regional efforts, such as the Chesapeake Bay Program, to international agreements or regimes, such as the International Commission for the Protection of the Rhine.

Concerns for the efficacy and durability of such collaborative arrangements has begun to be raised by scholars (Layzer 2008). Students of watershed partnerships have recognized that of the many collaborative efforts undertaken only a portion manage to adopt and implement plans and projects (Leach and Sabatier 2006:240). 1 Others have argued that partnerships are more effective if their plans and projects are formally adopted by governments and become legally enforceable (Landre and Travis 1996; Koontz et al 2004; Thomas 2003). Formal adoption may take a variety of forms, including government agencies adopting the product of collaborative efforts as their management plans, such as the U.S. Forest Service and the Northwest Forest Plan; memoranda of agreement among jurisdictions, such as the New York City Watershed Protection Plan; administrative agreements among states, such as the Platte River Recovery Plan; or even compacts among states, such as the recently adopted Great Lakes Compact. While formal adoptions and enforceable commitments do not guarantee success, such action does address concerns that voluntary collaboratives will decline or collapse over time as parties lose interest or fail to provide promised resources. 2

As interest in buttressing collaborative efforts increases, it is useful to examine the performance of formal, enforceable arrangements among independent parties. Many of these arrangements, just as with voluntary collaboratives, rely on consensus and unanimity rules to make collective choices. And, just as with voluntary collaboratives, a commonly expressed concern is that unanimity rules will make it difficult to come to agreement on policies and, at best, result in policies that reflect the lowest common denominator (aka "shallow agreements") (Coglianese 1997, 1999; Coglianese and Allen 2004; Kenney et al 2000; Breitmeier, Young, and Zorn 2006). Thus, empirically examining how enforceable arrangements grounded in unanimity rules perform may provide insight into the consequences of transforming voluntary collaborative efforts into enforceable efforts.

1 Among the 76 watershed partnerships studied by Sabatier and colleagues, 36 had not attempted any restoration projects (Leach and Sabatier 2006:240). As Leach and Sabatier (2006) and other scholars of partnerships note the value of partnerships resides as much in their process as in their outputs.

2 Admittedly, some of the benefits and strengths of voluntary collaboratives may be lost through formalization, such as broad based representation of interests, as some scholars have pointed out (Lach et al 2006). However, partnerships and formal arrangements need not be mutually exclusive; they may be blended. For instance, see Margerum (2007). 
This paper empirically examines the effects of unanimity rules in a setting that is highly conducive to stalemates or shallow agreement outcomes, interstate river compacts in the western United States. The interstate compact is the principle mechanism by which states allocate water from shared river systems. Compacts are legally binding and enforceable arrangements among independent parties in relation to highly salient collective goods - shared water supplies. Because of the salience of shared water supplies in these settings, parties can be expected to actively protect their own interests as they collectively make choices about how to allocate resources, administer rules, and develop strategies to comply with compact agreements. At the same time, compact parties are likely to be cautious in their joint action because interstate compact law supercedes state law. Consequently, it could be particularly challenging for compact commissions, which are composed of representatives of member states, to come to unanimous agreement on how to administer compact agreements and govern shared waters.

In this paper we use the lens of conflicts to better understand the governing capacity of interstate river compacts. Conflicts, which are disagreements among actors over problems, their causes, and their solutions, by definition pit actors' interests against each other. We examine all of the conflicts the 14 interstate compacts have been confronted with since their inception and compare the types of conflict issues resolved by compacts relative to other venues that have resolved conflicts related to interstate water allocation. These institutional settings include courts, legislatures, and federal and state agencies. Examining types of conflicts compacts resolve versus other venues sheds light on how institutional design is important. Second, our analysis compares the outcomes adopted by compacts in resolving conflicts compared to the outcomes adopted by alternative venues, offering a more complete understanding of the capacity of compacts to address the conflicts they have confronted over time.

\section{Interstate River Compacts}

In the early 1900s, conflict among water users spilled across the borders of western states. States and water users turned to courts to settle the interstate conflicts, but often came away dissatisfied with the outcomes, prompting water users and state water officials to search for regional solutions apart from courts. Additional pressure to settle interstate water conflicts came from the federal government after the passage of the Reclamation Act of 1902. The Bureau of Reclamation conditioned the construction of large scale surface water projects on states settling their cross boundary water conflicts. Eventually state water officials, with the support of water users, turned to compacts. Interstate compacts are constitutionally authorized agreements used by states to reduce conflict and promote cooperation over a wide range of issues, including taxation, pollution and the allocation of resources (Bowman 2004; Zimmerman 2002). Compacts operate as self-governing institutional arrangements, akin to treaties. As the U.S. Supreme Court noted in 1938 "The compact - the legislative means - adapts to our Union of sovereign States the age-old treaty making power of independent sovereign nations." (Hinderlider vs. La Plata River and Cherry Creek Ditch Company [304 U.S. 92 (1938)]). Interstate river compacts, which are most frequently used in the western United States, specify water allocation rules and in many cases establish a governing structure through which state representatives administer compact requirements. 
Early twentieth century advocates of interstate river compacts, such as Delph Carpenter, a principle designer of several compacts, such as the 1922 Colorado River Compact, viewed these arrangements as a superior method of resolving water conflicts among states compared to federal courts. Rather than engaging in lengthy court proceedings that often excluded relevant water users, Mr. Carpenter argued that states, on behalf of their citizens, should negotiate equitable water allocations to provide greater certainty and security for all water rights holders in a basin (Carpenter 1925). In addition, a governing structure would provide states regular opportunities to meet and discuss mutual water problems, develop regulations to administer compact terms and conditions, monitor water use, and settle conflicts. These expectations are reflected in the governing structures and terms established under the compacts. Most compacts provide for a governing body which is to meet annually and which has the authority to administer the terms of the compact, investigate various water issues as they arise, and monitor water allocations and diversions. Thus, states' officials expected that compacts would allow them to jointly provide for the efficient use and equitable apportionment of the water from shared rivers while promoting "interstate comity".

\section{The Performance of Interstate River Compacts}

Florastano (1994), in reviewing the literature on interstate compacts, noted that after 1970 public policy and political science scholars largely ignored compacts. The sparse contemporary literature that does exist primarily focuses on the conditions and factors that affect whether and what type of compact states are likely to join (Bowman 2004, Bowman and Woods 2008), why some efforts at compacting have failed, such as low level radioactive waste compacts (Weissert and Hill 1994), and the place of compacts in a federal system (Zimmerman 2002). But for an economic analysis of how compact water allocation rules allocate the risk of water shortages and a handful of dissertations devoted to single compacts, there are no empirical evaluations of the performance of interstate river compacts (Bennett and Howe 1998, Featherstone 1999; Hill 1992; Knox 2004).3

A small body of legal scholarship has, however, critically examined the capacity of compacts to manage interstate river basins. These scholars argue that interstate river compacts are inflexible and rigid, unable to respond to new challenges, such as endangered species, intensive groundwater pumping, or water quality issues (Giardot 1989; Grant 2003; Hasday 1997; Muys 2004; Sherk 2005). Such claims rest on a single case or two, none are based on a comparative analysis of multiple compacts.

The literature on interstate compacts has not attended to whether compact governments are capable of addressing conflicts and how they settle disputes -one of the principal goals of these institutional arrangements. There is, however, theoretical guidance from the institutional, collective choice, and the natural resource collaboratives literatures that informs our understanding of whether and under what conditions compact governments perform.

3 Although a few historic studies from the early 20th century discuss some of the advantages and disadvantages of interstate compacts, most of the scholarship assumes that compacts are an effective mechanism for resolving interstate disputes (Florestano 1994; Leach and Sugg 1959; Thursby 1953; Zimmerman and Wendell, 1951). 
Specifically, we look to this literature to consider what the design features of compacts imply for the types of issues and challenges compacts are capable of collectively addressing. Second, we examine the range of conflict resolution outcomes that may be adopted and how those outcomes may be affected by the institutional design features of compacts.

\section{Design Features and the Scope of Compact Performance}

One of the basic capacity features of any collective choice setting is its decision rules. All interstate river compact governing bodies use a unanimity decision rule to make collective choices.4 Unanimity rules and their effects on decision making and outcomes receive a mixed reception in the literatures on environmental problem solving and institutional rational choice. Many scholars in the environmental problem solving literature view partnerships and collaboratives as effective, in part because the use of unanimity rules slows down the decision making process, requiring extensive deliberation and consideration of all viewpoints. Over time as people interact and learn of one another's values and preferences, they devise solutions that better match the situation. Thus, unanimity is valued not just because it produces high quality decisions, but also because of the process it engenders. As has been widely noted in evaluations of partnerships and collaboratives, participants tend to be very satisfied with decisions, they view the decision process as fair, they build trust in one another, and they are more willing to work together with their fellow participants in future endeavors (Gaenslen 1996; Leach, et al 2002; Sabatier and Leach 2006).

Other scholars, however, point out that unanimity rules make decisions more difficult to reach (Miller 1985; Gaenslen 1996). The institutional rational choice literature has long acknowledged this challenge. A unanimity rule provides each participant in a collective choice process with a veto over decisions, allowing each actor to protect its interests and avoid exploitation by a majority, but at the price of very high decision making costs (Buchanan and Tullock 1962). Game theorists, therefore, treat compacts as "joint decision traps" because of the use of unanimity decision rules that allow a single member to veto any action (Scharpf 1997). As more decision-makers in an institutional setting have veto power, the more difficult it is to change the status quo (Tsebelis 1992). In other words, members of an interstate compact are unlikely to resolve a crisis because a mutually agreed upon solution will not be devised. As Scharpf (1997:145) explains in relation to unanimity rules,

In multilateral negotiations, rational self-interested actors would begin by proposing solutions favoring their own interests, and any communication among them would also be suspected of being self-serving and disingenuous. To work out a mutually acceptable solution under these conditions would be extremely difficult indeed.

The challenge that unanimity imposes on compact governments has been acknowledged by the critics of river compacts. As Muys (2004:10-11), a long time observer of and participant in attempting to resolve interstate water conflicts, argues:

4 The Bear River Compact allows for decisions to be made under a supermajority decision rule, however, in practice the commission uses a unanimity rule. 
Many western compacts require unanimity for official action interpreting or implementing compact provisions, thus conferring a veto power in a single state which can preclude its compact partners from administrative enforcement of asserted compact rights and obligations. This situation gives leverage to an upstream state alleged to be in violation of a compact to "stonewall" discussions and negotiations in the commission forum, since by virtue of its geographical advantage (i.e., "highority is better than priority") it may have already stored or used the volumes in dispute.

According to some scholars, the challenges imposed by such unanimity-based decision processes will ultimately result in inferior policy choices compared to other decision settings (Gregory, et al 2001). Since each participant has an effective veto the only alternative that may gain unanimous consent is the one that represents the lowest common denominator (Coglianese 1997, 1999). Gregory et al (2001) extend the critique beyond "shallow outcomes" to include process. They argue that consensus based processes may be designed to ease the burden of achieving unanimity by selecting issues more amenable to resolution, ignoring more intractable issues, selecting participants based on their ability to work cooperatively, limiting the range of interests, and suppressing views held by a minority of participants rather than fully vetting them (Gregory et al 2001:416-419).

In the case of interstate compacts, the question this raises is whether there are certain issues that that compacts may be more likely to attend to in making decisions. Based on Muys' assessment of compacts, distributional issues would likely be a particularly difficult issue to address because states will not relinquish existing rights or resources. Distributional issues, indeed, are commonly seen as a hindrance to the capacity of institutions more generally to address conflicts (Knight 1992). Moreover, when distributional dilemmas include asymmetric power claims - for instance where upstream states have control over the flows or storage of resources needed for a downstream state - those powerful upstream states have little incentive to work toward resolving their differences (Weissert and Hill 1994). Besides distributional issues, disputes involving multiple underlying problems or challenges increase the chances that the interests of the member states will diverge, "making individual action preferable to cooperation" (Weissert and Hill 1994:30). In sum, the implication is that unanimity rules may constrain compact governments to addressing only the simplest of conflicts.

Another institutional design feature of interstate river compacts that may limit the scope of compacts in addressing conflicts stems from the fact that interstate compacts do not directly govern or regulate the citizens of states. Rather, state governments make enforceable commitments to one another. Therefore individual member states, on their own, must enforce compact requirements with their citizens. For instance, assume a compact requires that an upstream state maintain minimum stream flows for a downstream state. If individual water users in the upstream state divert more water than the state is entitled to under the compact, the compact commission would not have the authority to directly regulate the water diversions of users in the upstream state. Regulating those diversions would remain under the authority of the upstream state. The compact commission may request that the upstream state correct the situation, but shutting down water users depends on the willingness of the upstream state authorities to do so. 
States have the legal and institutional capacity to pass laws and regulations in order to ensure that their citizens do not use water in a way that violates compact rules. However, states may not always have the incentives to do so. As Derthick (1974) points out in a study of regional governments, compacts may not be warmly embraced by state agencies whose functions they challenge and thus state agencies may be reluctant to act against their clientele in order to satisfy an interstate compact. Also, compacts may force state elected officials into difficult positions, such as shutting down their own citizens' well-established water uses in order to serve the citizens of a nearby state. As a result, Derthick (1974:192) argues, "Regional action proceeds within a narrow sphere or at a slow pace".

In sum, while recent literatures on collaborative, or inter-jurisdictional institutions suggests that such institutions are well-suited to highly conflictual settings (Lubell et al. 2006), the literatures on institutional choice, compacts, and regional governments indicates that the capacity of these institutions to resolve conflicts is more limited. These limitations, at least in theory, result from unanimity decision rules, which compacts and other inter-jurisdictional agreements commonly use, as well as the incompatibility between the inter-state or collaborative institutional agreement and the rules or policies of the members of those agreements. These overarching institutional design features, as well as the way these features play out in a water management context, highlight the types of conditions under which compacts' would be expected to address conflicts. Specifically, those conditions where compacts are likely to address conflicts, according to the literature, include those that do not 1) involve distributional issues, 2) pit upstream interests against downstream interests, 3) involve multiple underlying issues, or 4) invoke differences between states laws and compact commitments.

\section{Outcomes of Compact Conflicts}

The institutional design features of compacts not only limit the scope or types of issues they will address, but how they address those issues and what policy outcomes they produce. In particular, under unanimity decision rules, commissions should be expected to take actions that require fewer decision making costs. What types of actions will those be? Here we turn to the work of Crawford and Ostrom (1995) and Ostrom (2005) to explore these factors.

In addressing and resolving conflicts, compact commissions may engage in institutional changes. Institutional changes can come in the form of strategies, norms, or rules (Crawford and Ostrom 1995; Ostrom 2005). Ostrom (2005:17-18) defines strategies as "individual plans of action"; norms as precepts or maxims "for prudential or moral behavior"; and rules as "shared understandings by participants about enforced prescriptions concerning what actions (or outcomes) are required, prohibited, ox permitted" (italics in original).5 Among the types of

5 Crawford and Ostrom (1995) created an institutional grammar and syntax to distinguish between strategies, norms, and rules. In this paper we do not use norms because we could not distinguish between norms and strategies in the variety of documents from which we culled data. According to the Crawford and Ostrom (1995) syntax, a strategy consists of who it applies to (attributes), the actions that may be taken (aim), and the conditions under which the actions may be taken (conditions). In addition to attributes, aim, and conditions, norms include a deontic, that is whether the actions are permitted, forbidden, or required. Since we could not consistently distinguish between strategies and norms, we decided to be conservative in our judgments and 
institutional changes, strategy changes are assumed to be easier to establish. Strategy changes are akin to the exercise of discretionary authority and are less costly to engage in than are rule changes because strategy changes do not require action on the part of a rule making body whereas rule changes do. For instance, for a number of years the Republican Compact Commission regularly requested its Engineering Committee to experiment with different ways of measuring water consumption and water diversions (Republican River Compact Commission 1960; Republican River Compact Commission 1970). These may be thought of as strategies or plans of action intended to develop information about alternatives for implementing the compact allocation rule.

In contrast to strategy changes, rule changes occur when a collective choice body, like a commission, exercises its rule making authority and adopts a new rule. Continuing the above example, the Republican River Compact engineering committee would, based on its findings from different methods of calculating water use and diversions, recommend that the commission revise the implementation rules and formally adopt a new type of water measurement. The Commission regularly followed the advice of its engineering committee and several times amended the rules (Republican River Compact Commission 1960; Republican River Compact Commission 1970).

Are there certain types of rule changes that are more likely than others? In the instances when commissions do adopt new rules, using the work of Ostrom (2005), it is possible to develop expectations concerning the types of rule changes that will be more common. As part of the Institutional Analysis and Development framework, Ostrom (2005) identifies different levels of action with each level of action in part structured by different types of rules. The day to day level of action, the operational level, is structured by operational level rules that constrain and guide day to day activities. For instance, the amount of water an irrigator may divert is defined by an operational level rule. The collective choice level of action involves actors devising operational level rules. This level of action is structured by collective choice rules that specify who may participate in rule making activities and how the rule making process proceeds. Monitoring and enforcement of operational level rules also occurs at the collective choice level. For instance, the decision rule used by compact commissions is a collective choice level rule. Finally, the constitutional choice level of action involves actors devising rules about rule making activities. For instance, compact commissions, when first constituted, engage in constitutional choice action and devise and adopt "rules of procedure" that define what constitutes a quorum, specify decision rules used by commissions for different types of action, create monitoring systems and so forth.

assumed that at the least we identified strategy changes. Furthermore, Ostrom (2005) distinguishes between formal rules and rules-in-use. Rules-in-use are those rules that participants in an action situation use in practice, they may differ from the formal rules adopted by a collective choice body. In this study we do not distinguish between the two types of rules again because of the types of documents we used to cull data from. In general, newspapers, commission reports and minutes, public agency documents, and court cases do not make the distinction between the two types of rules. According to Ostrom (2005) the most common means of identifying rules-in-use is through participant observation and interviews. 
Ostrom (2005) suggests that all things being equal, it is less costly to change operational level rules than collective choice rules, and less costly to change collective choice rules than constitutional choice rules. Thus, operational level rule changes should be more common than collective choice rule changes, and collective choice rule changes more common than constitutional choice rule changes. Overall, in resolving conflicts, we would expect that compact commissions are more likely to adopt new strategies than to adopt new rules, and if they adopt new rules they are more likely to be operational level rules. Thus, the types of solutions likely to be adopted by compact commissions are expected to cluster around strategies and operational rules changes, as these are likely to be less costly and easier to devise.

\section{Data and Methods}

The data for the analysis comes from a study of 14 interstate river compacts in the western United States and water conflicts that have arisen in the basins governed by these compacts (see Table 1). Focusing on western compacts controls the variability in the legal and physical setting that can drive conflicts. As the western United States is relatively arid, the legal institutions that allocate water in the West are markedly different from the East. Western states allocate water using the doctrine of prior appropriation - meaning those citizens who put water to beneficial use first have the priority to use flows during times of scarcity. 6

The unit of analysis is a conflict case related to an interstate water compact within the 14 river basins in our study. Our research identified 23 such conflicts since the compacts were negotiated. In general, we defined conflicts as disputes of two or more parties over the allocation, distribution or scarcity of water resources, water quality, protection of endangered species and habitat within the river basin's boundaries that are governed under an interstate compact, in which the parties disagree over the issues, causes, and solutions . Those conflicts related specifically to compacts (versus more general water conflicts within the compact basin), involve disagreements over the interpretation, compliance or enforcement of the 14 compacts. Coded information on the conflicts included the types of issues underlying the conflict, the parties to the conflict, the venues that considered and resolved the conflict, and the types of strategies and rules solutions adopted. 7 In addition, we have coded data on the constitutional,

6 The Colorado River Compact is not included because it is significantly different from the other fourteen, not only in terms of the number of states it encompasses, but also because the Compact is one piece of a complex of laws governing the river that are collectively known as "the law of the river". Furthermore, unlike the other fourteen compacts in which the federal government and federal water agencies play limited roles in their administration, the federal government, through the Secretary of the Interior, is a dominant actor in administering the river.

7 All of the coding decisions for these variables were interpreted by coders after detailed analyses of the supporting documents for each case and where questions of interpretation arose, cases were reviewed independently by two coders to ensure inter-coder reliability. Rule changes were identified by whether a collective choice decision was made that resulted in new rules. Operational rule changes were identified as rules that directed a change in day to day operations, such as how to measure a water diversion, or how to release flood waters from a reservoir. Collective choice rules were identified as rules directed at the activities of collective choice bodies or collective choice activities, such as monitoring water withdrawals. Constitutional 
collective choice, and operational level rules constituting the compact and the operational decisions and actions of the compacts' administrations. Data sources for coding conflicts come from news stories, court cases, compact commission reports and meeting minutes, historic documents from the commissions, and law reviews. Table 1 below provides an overview of the compacts and number of conflicts.

\section{[INSERT TABLE 1 ABOUT HERE]}

The first component of the analysis examines the types of conflicts addressed by compact commissions compared to the types of conflicts addressed by other venues. That is, the 23 compact related conflicts were addressed in different venues - commissions, courts, state or federal agencies, and state legislatures. The expectation, based on the literature review, is that compact commissions, because of their institutional structure, will address relatively simple conflicts whereas the more divisive and complex conflicts will be addressed in other venues. For this portion of the analysis, data are drawn from our coding of the types of actors involved in each conflict and the issues underlying the conflict. The issue categories in our dataset include: a) distributional issues, b) upstream-downstream issues, and c) compatibility issues between state laws and compacts. We also include a measure of conflict complexity, defined as those conflicts that involve issues a, b, and c above, as well as two or more of the following issues: water scarcity, timing of water flows, provision of public goods (e.g. flood control), or differing interpretations of water information or hydrologic models.

The second part of the analysis focuses on the resolution of conflicts. The decisions made by the venues that addressed the conflicts were coded based on the grammar of institutions developed by Crawford and Ostrom (1995) and Ostrom's levels of action (2005). Thus, the initial coding determined whether a specific decision maintained the status quo, represented a change in strategy, or constituted a rule change. If a rule was revised or adopted, it was then coded as either an operational, collective choice, or constitutional choice rule change. The expectation based on the literature review is that commission adopted solutions will tend to cluster around strategy and operational rule changes as they require fewer decision making resources compared to collective choice and constitutional choice rule changes.

Fuzzy Set Qualitative Comparative Analysis (fs-QCA) developed by Charles Ragin $(1987 ; 2000)$ is used to analyze the data. Fs-QCA relies on Boolean algebra to assess the combinations of necessary and sufficient conditions that are related to an outcome of interest thus drawing upon fundamental components of case-study research (Ragin 1987; 2000). Yet, unlike case-study research, this approach is particularly useful for handling medium-N data sets $(n=10-65)$, and those with a large number of potentially relevant, and often highly correlated, causal conditions. It should be emphasized that fs-QCA does not mimic variable based statistics, which examine the effect of each explanatory variable on the dependent variable, holding the values of independent variables constant. In contrast, fs-QCA emphasizes the "set relations" among social phenomena, which as Ragin (2009) notes are the building blocks of most social

choice rules were identified through revisions to the compact's constitution. Strategies were identified by evidence of actions of public managers or officials changing. 
science theories. 8 In other words, it allows us to evaluate empirically the theoretical assertions that highly complex conflicts or distributional conflicts are not part of the set of conflicts addressed by commissions. Additionally, with the fs-QCA, the analysis typically moves between the Boolean approach and an in-depth examination of key cases in order to ground the findings. Consequently, discussions of specific cases are used to illustrate how the fs-QCA results play out in practice.

Using the fs-QCA technique, variables are coded on a scale of 0 to 1 , as being "fully out" (0) of the variable set of interest or "fully in" (1). The fs-QCA method then constructs a "truth table" that contains all of the theoretically possible combinations of conditions that relate to the model's outcome. Each row of the truth table shows the number of actual cases in the data that match each possible combination of conditions. After minimization, the fs-QCA analysis derives a solution for the minimal conditions that are sufficient to lead to the outcome of interest. The model solution uses Boolean algebra notation (where "*" equals "AND", "+" equals "OR") to depict the combination of conditions that are sufficient for the given outcome. The presence of conditions is shown in all upper case letters, whereas the absence of conditions is shown in lower cases.

\section{Findings}

Table 2 presents all of the different conflict "configurations" (or combinations of conditions) that compact commissions have resolved and their frequencies. The explanatory variables for this portion of the analysis includes those previously described: 1) whether the parties involved are interstate ("interstate parties"), 2) whether the conflict involves distributional issues ("distributional", 3) whether the conflict involves upstream versus downstream issues (upstream/downstream), 4) whether the conflict involves issues of cross-scale compatibility between compact rules and state laws ("compatibility"), and 5) the complexity of the underlying conflict issues ("complexity").

\section{Types of Conflicts Resolved by Compact Commissions}

Of the 32 possible combinations of conflicts, four combinations have been addressed by compact commissions and eleven combinations by other venues (ignoring redundancy). All four types of conflict configurations addressed by commissions involve interstate parties only, as would be expected because interstate river compacts are designed to address interstate issues (see Table 2, each row represents a conflict configuration). Furthermore, six of the eight conflicts consist of configurations of conditions that involve distributional issues (row 1), or distributional issues and upstream/downstream issues (row 2), or compatibility issues (row 3). For instance, the most common type of conflict configuration addressed by compact commissions is a conflict characterized by interstate parties and distributional issues, but no compatibility, upstream/downstream or highly complex issues. Compact commissions have addressed three such conflicts (see the first row of Table 2).

Two of the three conflicts emerged in the Bear River Basin. In negotiating the Bear Compact in the 1950s, states disagreed over whether the compact should guarantee that water

8 For more in-depth information on the fs-QCA method and software see http://www.u.arizona.edu/ cragin/fsQCA/ 
storage needs projected for irrigators on one of the tributaries of the Bear would be met. After one of Idaho's congressional representatives from that region threatened to delay the ratification of the compact, the compact commission agreed to include provisions to ensure that that those irrigators would retain rights to develop a certain volume of long-term storage, rather than allow that water to be used for other allocations, settling the dispute. More recently, the Bear River commission was faced with a dispute over how to account for groundwater impacts on stream flows when determining how to allocate water during low flow periods in the downstream portion of the basin. The commission eventually resolved the dispute and adopted new rules after muddling through with various interim rules (a set of formal, but temporary, administrative guidelines that served as placeholders until the commission could assess and address the entire set of underlying accounting issues). In the third case, the Arkansas River Compact commission struggled with devising a process for storing and allocating flood waters captured in the John Martin Reservoir among Colorado and Kansas irrigators, the primary reservoir controlled by the compact commission. The commission representatives argued over a variety of methods for storing and allocating flood water over a period of years before finally adopting a particular operational approach that settled the conflict.

These findings suggest that compact commissions, even though they use unanimity decision rules and they cannot directly regulate water users, nevertheless are capable of addressing relatively difficult conflicts. That is, in spite of their somewhat awkward institutional features they do address a variety of types of conflicts, not just simple ones.

\section{[INSERT TABLE 2 ABOUT HERE]}

Are there particular conflict configurations that only commissions and no other type of venue resolve? Have commissions carved out a conflict niche for themselves? The fs-QCA Boolean minimization process derives a solution that represents the sufficient (and possibly necessary) conditions representing the types of conflicts compact commissions address. The model for this analysis includes the five key explanatory variables identified in Table 2 to assess the combinations of conditions that are associated with a compact commission addressing a conflict (COMPACTAD):

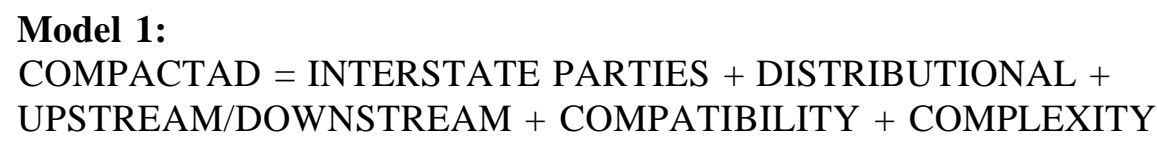

For this model, there are $2^{\mathrm{k}}\left(2^{5}\right)$ or 32 logical (or potential) combinations of conditions. In this data set 12 of the 32 logical combinations are present, as shown in Table 2. Analyzing the 12 combinations for sufficiency produces the following solution, shown in Figure 1:9

\section{[INSERT FIGURE 1 ABOUT HERE]}

9 See Appendix A for a description of how QCA "solves" Model 1 producing the solution in Figure 1. 
Recall, fs-QCA emphasizes "set relations" among social phenomena, and Figure 1 shows that the solution to Model 1 identifies the set of conflicts addressed by commissions only and no other venue. The conflict configuration included in the set consists of interstate parties and no distributional issues and no compatibility issues and no upstream/downstream issues. That is, every instance of a conflict characterized by this particular combination of factors is addressed by a compact commission. No other type of venue addressed this combination of factors.

The fs-QCA method relies on two measures to assess the robustness of the solution consistency and coverage. Consistency is a measure of how frequently the solution's conditions are a subset of the outcome - or how often the combination of conditions in the solution agrees on the outcome. A consistency score of $100 \%$ means of the twenty three conflict cases in this data set, a conflict case consisting of interstate parties and no distributional issues, and no compatibility issues, and no upstream/downstream issues always is addressed by a commission. 10 Coverage establishes the empirical relevance of the solution by measuring how much of the outcome is explained by the conflict conditions. Notice the solution contains two cases (or 25 percent of all of the cases addressed by compact commissions). The coverage score of the solution for Model 1 is relatively small: a single configuration of conflict conditions that contains two cases. In other words, while commissions address a number of different conflict configurations, only a single configuration is resolved by compacts and no other venue.

Each of these cases involved conflict spurred by organizations who were not parties to the compacts but whose actions were perceived as threatening the compacts' water allocation rules. The proposed actions promoted disagreement and intense, sometimes heated, discussions among compact representatives who eventually agreed upon a common response to the perceived threat. For instance, one case involved an Army Corps of Engineers proposal to build a reservoir on the Purgatoire River above Trinidad, Colorado, for flood control purposes. The Purgatoire is a major tributary of the Arkansas River. Representatives on the Arkansas River Compact commission from both Colorado and Kansas expressed grave concern that the project would reduce river flows. The Kansas representatives opposed the project, the Colorado representatives split, and the federal representative, who was the nonvoting chair of the commission, supported the project. In a straw vote, the Colorado representatives decided to accede to the concerns of those who opposed the project and the commission unanimously voted against the project over the strenuous objections of the chair. The commission agreed to reconsider its original vote, at the urging of the chair, and after several meetings over the course of a year developed a compromise solution that allowed the commission to vote in favor of the project.

10 The fs-QCA method can derive three different types of solutions: 1) the most parsimonious, 2 ) the most complex, and 3) the intermediate solution. The solution coverage score provides a way to compare which of the three different solutions explains the largest proportion of the outcome. For this model, we used the more complex solution. In addition, the consistency score measures how often the solution results in the outcome. A low consistency score, such as .25 , means that the solution results in the outcome only $25 \%$ of the time. In other words, the solution does not capture the full range of conditions that lead to the outcome. A high consistency score, such as 1 , indicates that the solution accounts for the combination of conditions that lead to the outcome. 
As Table 2 exhibits, compact commissions have addressed a variety of types of conflicts, but what Model 1 tells us is that so too have other venues. Only the conflict configuration of the last row is addressed by compact commissions and no other type of venue. The conflict configurations in the other rows are addressed by compact commissions and other types of venues. Compact commissions address many more difficult conflicts than the literature suggests, but they have been able to carve a niche for themselves only in relation to relatively simple conflicts.

\section{Types of Conflicts Resolved Outside of Compact Commissions}

How do the types of conflict configurations addressed by commissions compare with the types of compact conflict configurations addressed by venues other than commissions? Table 3 presents the conflict configurations and their frequencies addressed by courts, federal and state agencies and state legislatures.

\section{[INSERT TABLE 3 ABOUT HERE]}

These alternative venues address 15 conflicts consisting of 11 different conflict configurations. Non-compact venues address more conflicts and more diverse configurations of conflicts than do compact commissions. No single configuration dominates, each of the eleven configurations appear once or twice. Running Model 1 will likely produce many sufficient configurations of conflicts. It is possible to reduce the many configurations by identifying the minimal configurations sufficient for an outcome. Model 2, uses the same variables as Model 1, but looks for the minimized solution of conditions associated with conflicts not addressed by compact commissions (-COMPACTAD).

\section{Model 2: \\ -COMPACTAD = INTERSTATE PARTIES + DISTRIBUTIONAL + COMPATIBILITY + UPSTREAM/DOWNSTREAM + COMPLEXITY}

The solution for this model is represented in Figure 2 below.

\section{[INSERT FIGURE 2 ABOUT HERE]}

The solution for Model 2 shown in Figure 2, consists of three sets of conflicts addressed by alternative venues only and not compact commissions. A sufficient condition for alternative venues to address conflicts is for the conflicts to involve intra-state parties (or no interstate parties). Of the fifteen conflicts, five involved intra-state parties and all five were addressed by non-compact venues, accounting for $33 \%$ of the 15 conflicts. These conflicts appear in rows 1-3 of Table 3. This provides parallel support for Model 1 - compact commissions address conflicts among interstate parties but not among intra-state parties.

A second conflict configuration consists of conflicts that involve upstream and downstream conflicts but not distributional conflicts. These conflicts appear in rows 4-6 of Table 3, accounting for $27 \%$ of the 15 conflicts. All four cases entail downstream states claiming compact violations by upstream states and all four are eventually decided by the U.S. Supreme Court, and are discussed in greater depth in the next section. 
A third conflict configuration addressed by alternative venues and not by compact commissions consists of distributional issues and multiple underlying issues. Recall, complexity is measured as a conflict that exhibits two or more of the following characteristics: water scarcity, timing of water flows, provision of public goods such as flood control, or differing interpretations of water information or hydrologic models. In other words, these conflicts are challenging; not only is a zero-sum distributional conflict present, but it is compounded by additional issues, such as water quality. These conflicts appear in rows 7 and 8 of Table 3 and they constitute 3 or $20 \%$ of the conflicts addressed by alternative venues. One of these conflicts emerged in 2002 in the Bear River basin when PacifiCorp, which operates hydropower dams and diversions from Bear Lake (a natural lake the central Bear River Basin) petitioned to dredge the lake to create a canal to bring water to irrigators. According to compact, water below the lake elevation of 5,902 feet is designated emergency storage for irrigators; drought conditions since the late 1990s had led to lake levels approaching that limit. While PacifiCorp was obligated to comply with the compact's storage requirements, the company had also agreed in 1995, via the Bear Lake Agreement with home owners and conservationists, that it would not pump the lake below 5,904 feet level. PacifiCorp's proposal to pump water for irrigators - which would ensure compliance with the compact - thus caused outrage among homeowners, recreation groups and native trout conservationists concerned that lowered lake levels would impair habitat and recreation areas. Ultimately, the conflict was addressed through negotiations with federal and state agencies, without the involvement of the compact commission. The U.S. Army Corps of Engineers gave PacifiCorp the dredging permit under the condition that it would provide passage for Bonneville Cutthroat Trout. PacifiCorp also agreed to provide money so the Utah Department of Parks and Recreation could deepen the entrance of Utah State Park Marina.

Analyzing the types of conflicts compact commissions address compared to those addressed in alternative venues sheds considerable light on the conflict resolution ability of compact commissions. Compact commissions address a variety of conflicts, even those that involve distributional issues that the literature suggests they should not be capable of given their institutional structure. Comparing the commission addressed conflicts with alternative venue conflicts, however, suggests two conflict configurations appear outside of their grasp to address, one involving serious violations of compact commitments by upstream states, and the other involving distributional issues combined with other underlying issues making for particularly difficult conflicts.

\section{Outcomes of Conflicts over Interstate Compacts}

The institutional structure of compact commissions should not only affect the types of conflicts addressed, but also the types of conflict solutions adopted. As noted earlier, theory suggests that compact commissions will adopt solutions associated with lower decision making costs. Following the work of Ostrom (2005) we expect solutions adopted by compact commissions to cluster among strategies and operational rule changes. For instance, a compact commission may experiment with different strategies for storing flood waters in a reservoir without changing the reservoir's operating rules. In light of such experimentation, the commission may choose to revise operational level rules for the reservoir.

Table 4 arrays venues by conflict solutions. Final decisions are largely made by compact commissions and courts. Of the 23 resolved conflicts, commissions adopted final decisions 
among 8 of them and courts among 10 of them. The remaining 5 conflicts were resolved by federal or state agencies and legislatures.il As expected, sixteen, or 70\%, of conflict solutions involve operational rule changes, strategy changes, or the maintenance of the status quo. Seven, or $30 \%$, of conflict solutions involve collective choice or constitutional choice rules.

\section{[INSERT TABLE 4 ABOUT HERE]}

Compact commissions resolve conflicts by revising the operational rules used to administer the compacts. The six operational rule changes adopted by commissions involved revising water allocations or water accounting procedures or both. For instance, the Rio Grande Compact Commission developed a uniform accounting procedure for tracking states' water debits and credits. To that point, each state, Colorado, New Mexico, and Texas, used a different accounting method for tracking debits and credits with states arguing over which method was appropriate. The Bear Compact Commission was particularly active in addressing conflicts through operational rule changes. In two instances the Commission revised allocation rules, granting an apportionment of water to Idaho irrigators and devising special allocation rules for end of the river water users during times of emergency. In a third conflict, the Bear Commission revised methods for tracking water diversions.

A much less likely conflict resolution scenario is for compact commissions to revise collective choice or constitutional choice rules. The single instance of a collective choice rule change occurred with the Arkansas River Compact Commission. As discussed previously, the Army Corps of Engineers in cooperation with the Bureau of Reclamation proposed to construct a flood control and storage reservoir above Trinidad, Colorado on the Purgatoire River, the major tributary of the Arkansas River. Kansas and Colorado water users opposed its construction, fearing that once built, it would be used to store not only flood waters, but river water governed by the Arkansas Compact. Their opposition was overcome when the Compact Commission revised its collective choice rules, granting itself the authority to approve the operating plan for the reservoir. While the Bureau of Reclamation, who would operate the reservoir, technically did not need the Commission's approval, the Bureau in practice moves forward only with the consent of the states involved. The Arkansas Compact Commission and the states of Colorado and Kansas supported the reservoir's construction, it was built, and the Commission is now an active participant in ensuring the Bureau operates the reservoir according to an agreed upon operations plan.

The single instance of a Commission engaging in constitutional choice rule making involved the Bear Compact Commission. The Bear Compact was adopted and implemented in 1955. Over the course of the next decade and a half, the member states expressed increasing

11 Of the four conflicts resolved by state or federal agencies, the agencies themselves were at the center of the conflicts. Typically, the agency engaged (or failed to engage) in an action that sparked conflict. For instance, the status quo case involved the Bureau of Reclamation withdrawing a plan to develop the Bear River basin after a storm of protest from a wide variety of water users, thereby maintaining the status quo within the Bear River Basin. The operational rule change by a state legislature involved the legislature in adopting a water storage contract with a federal agency. 
dissatisfaction with the Compact's inability to address a number of pressing issues, such as the need for new upstream storage projects, the protection of downstream water rights from upstream storage development, and the impacts of groundwater pumping on surface water flows. To address the conflicts that flared up over these issues, the commission began negotiating major revisions to the existing compact. After a decade of negotiations, the commission unanimously adopted the revisions, which were then approved by the states' legislatures.

The outcomes of conflicts addressed by commissions entail revising the operational rules of compacts. Only on rare occasions do commissions revise their collective choice rules or attempt substantial revisions of a compact. Commissions, charged with administering compact requirements, largely focus their conflict resolution efforts on revising administrative rules.

The pattern of conflict solutions adopted by courts differs notably from those adopted by commissions, revealing a very different role for courts in resolving conflicts. Solutions adopted by courts tend to cluster into two groups - status quo outcomes and collective

choice/constitutional choice rule changes. Among the four conflicts resulting in status quo outcomes, three involve private parties challenged decisions made by compact commissions or compact related actions of state or federal water agencies. In each case, the deciding court found in favor of the commissions and agencies. In the remaining conflict the lawsuit was dismissed because of the failure to include an indispensable party. The conflicts resulting in status quo outcomes may be thought of as raising "accountability" issues. Private citizens requested independent third party reviews of the actions of public entities, a quintessential role for courts. 12

Of the five conflicts addressed through collective choice or constitutional choice rule changes all were brought before the U.S. Supreme Court. The first of these cases to be filed raised the question of the relationship between state water law and the water allocation rules of compacts. The U.S. Supreme Court decided that compacts supercede state law, thus the Colorado State Water Engineer was correct in curtailing water diversions that were otherwise legal under Colorado law in order to meet La Plata River Compact requirements (Hinderlider vs. La Plata River and Cherry Creek Ditch Company [304 U.S. 92 (1938)]).

The other four Supreme Court cases involved downstream states bringing suit against upstream states for failure to meet their compact obligations. In each of the cases, the downstream states repeatedly raised noncompliance issues before the compact commissions for a decade or more, but the upstream states, through their veto power, prevented commissions from taking action. At the root of the noncompliance issues was rapidly expanding and lightly regulated groundwater pumping in each of the upstream states, groundwater pumping that affected surface water flows. In each case the Supreme Court found in favor of the downstream states. In three of the four cases, compacts were revised, and in all four cases, state water laws were revised. These cases illustrate the limitations of the compact form of government and the importance of having access to a court of equity to adapt compacts to changing circumstances.

12 In the only court case involving an operational level rule change, how a federal water agency exercised its authority in signing water contracts was challenged. The court required an agency to conduct an environmental impact statement for its water marketing program. 
The three revised compacts were the Pecos, the Republican, and the Arkansas. Revisions centered on creating monitoring and enforcement systems that would allow compact commissions to readily determine compliance and to access mechanisms for correcting noncompliance. For instance, the Supreme Court approved the adoption of a hydrologic model developed by Texas, the downstream state, which accurately reflected flows of the Pecos River. In addition, the Court approved the appointment of a river master, an independent third party, to administer the model. If New Mexico under delivers water to Texas for three consecutive years the river master has the authority to take over the administration of water in the New Mexico portion of the Pecos River Basin. Prior to the creation of monitoring and enforcement mechanisms, the downstream states in these three compacts did not have the ability to ensure compliance on the part of upstream states. Furthermore, in all four of these U.S. Supreme Court cases, upstream states adopted new water laws and revised existing water laws that more tightly regulated water use to ensure the states' stayed within their compact water allotments.

As others have pointed out, Supreme Court cases are often costly drawn out affairs to be avoided if possible (Muys 2004; Muys et al 2007; Grant 2003). As these cases indicate, however, the Supreme Court has an important role to play in relation to interstate river compacts. In each case, the states took advantage of the equity powers of the court to develop agreements, and negotiate critical institutional changes in compact governing structures.

Outcomes adopted by commissions largely follow the expectations derived from the institutional design literature. In resolving conflicts, commissions adopt operational level rules; they rarely adopt collective choice or constitutional choice rules. Commission outcomes differ notably from outcomes adopted by courts to resolve conflicts. The outcomes of court resolved conflicts tend to cluster around collective choice and constitutional choice rule changes. This finding reflects the use of the Supreme Court by members of compacts to resolve particularly divisive conflicts by revising the compacts to enhance the capacity of commissions to better administer the compacts and to resolve more challenging conflicts.

\section{Conclusion}

This paper represents the first empirical examination of the capacity of western interstate river compacts to address conflicts. The ability of compact commissions to address water conflicts has been called into question by their critics and the institutional design literature. Both point to their awkward institutional structure - the use of unanimity rules and the inability to directly regulate water users - to suggest that commissions will perform poorly in resolving conflicts. Contrary to these expectations commissions have addressed a variety of conflicts. Zero sum distributional conflicts are the most common conflict type they have addressed. This is notable in that distributional conflicts are considered among the most difficult to resolve (Scharpf 1997; Miller 1993; Fearon 1998; Alcock 2002). Overall, it appears that unanimity rules do not provide as high a decision making barrier as the institutional literature suggests. 13

13 This finding is compatible with studies of watershed partnerships and international environmental regimes that have found that such organizations, largely grounded in consensus and unanimity rules, are capable of realizing goals and implementing projects (Leach et al 2002; Breitmeier, Young, and Zorn 2006). For instance, Leach, et al (2002:662) found that just over 
Furthermore, compact commissions commonly solve conflicts by revising rules; usually operational level rules that change water allocations among water users or that allow more precise accounting of water diversions. These are not minor solutions. The foundation of institutional arrangements for governing water is determining and tracking water allocations. While performing better than expected, that performance may be overstated without placing it within a comparative context. How do compact commissions perform compared to alternative venues, such as courts, federal and state agencies, and state legislatures in resolving compact related conflicts?

Several findings from this study are notable. First, alternative venues address similar types of conflict configurations as do commissions. Thus, conflicts that exhibit interstate and distributional issues or interstate, distributional, and upstream downstream issues may appear in a variety of venues. Second, two types of conflict configurations, however, are only addressed in alternative venues and never by commissions. These conflicts are characterized by deep-seated differences between upstream and downstream states regarding compact requirements that commissions were not capable of addressing. Seeking relief before the Supreme Court, member states have engaged in significant institutional revisions of compacts. Or, the conflict configurations are characterized by greater numbers of issues that not only include distributional concerns, but also differences over the interpretation of hydrologic models or issues around water quality. These too have ended up before courts, but not the Supreme Court and they have resulted in a court affirming the action of a commission in two cases, and a court limiting the discretion of an agency in a third instance. Compact commissions may do better at addressing difficult conflicts than expected, but compared to alternative venues, they do not address the most complex conflicts. Courts are important partners with commissions in solving conflicts. Courts provide an independent venue that private citizens may call upon to review the decisions and actions of commissions. Furthermore, they provide a forum for states to resolve deep-seated conflicts and to hold one another accountable for realizing their compact commitments and for revising and adapting compacts to better fit changing circumstances.

The findings of this study suggest several policy implications for water managers in transboundary settings in the western United States. As the primary mechanism used by western states to allocate water from shared rivers, they are likely to come under greater strain as expanding populations and growing economies increase demand for water, while concurrently water supplies become more fragile in the face of ecosystem threats and climate change. Assuming that compacts cannot resolve pressing dilemmas, based on anecdotal or limited theoretical guidance may push policymakers to jump into ill-informed reforms, or worse, throw up their hands and give into what Ostrom has called "self evident truths" (Ostrom 2000). This study suggests that that formalizing voluntary collaboratives need not come at the price of indecision, shallow agreements, or joint decision traps. Compact commissions are quite capable of resolving a variety of conflicts as they interpret and administer the terms of compacts, particularly in partnership with other venues, and thus wholesale revisions may not be necessary as suggested by the authors of the recently released Model Interstate River Compact (Muys et al 2007). Rather, it may be more fruitful to address specific shortcomings of compacts. For

half of the 44 watershed partnerships in their study, most of which used unanimity or consensus rules adopted plans and projects and began implementing them. 
instance, most compacts lack compliance mechanisms, such as dedicated sources of water that upstream states may draw upon to cover shortfalls in water deliveries, or independent river masters who are trusted by all members and who may take over water administration during times of shortage. Incorporating compliance mechanisms may reduce the incidence of serious conflicts among compact members.

For scholars of institutions and natural resource management, this paper demonstrates the value of comparative analysis in examining how a particular institutional arrangement performs and addresses problems. Comparing the institutional outcomes of 23 conflict events using a Boolean QCA method required consistent and reliable coding of complex "action settings" (conflicts), the diverse venues that address conflict events, as well as the conflict resolution decisions made by the venues. Our application of a well-established framework, the Institutional Analysis and Development Framework, provided the empirical grounding and rigor for coding the relevant features of both the conflicts and institutions. As the first study to apply this framework to interstate river conflicts and their outcomes, we hope our work provides a foundation for future data collection and comparisons with other conflicts or institutional settings. 14 In coding and comparing the data challenges arise, such as how to determine what constitutes a clear strategy change versus a rule change. We recognize that human interpretation of institutions and their features is open to debate and interpretation. Undoubtedly, our application of the IAD framework to transboundary water conflicts and conflict resolution can be further developed and tested. Extending our coding scheme and analysis to different settings, such as intrastate conflicts or conflicts in international transboundary basins may be useful next steps.

14 The coding forms for this study can be made available by contacting the authors. 


\section{References}

Alcock, Frank. 2002. "Bargaining, Uncertainty, and Property Rights in Fisheries". World Politics 54(4):437-461.

Bennett, Lynne L., and Charles W. Howe. 1998. "The Interstate River Compact: Incentives for Non-Compliance". Water Resources Research 34(3): 485-495.

Besso, Michael 2005. "Constitutional Amendment Procedures and the Informal Political Construction of Constitutions". Journal of Politics 67(1): 69-87.

Bowman, Ann. 2004. "Horizontal Federalism: Exploring Interstate Interactions". Journal of Public Administration Research and Theory 14: 535-546.

Bowman, Ann and Neal Woods. 2008. "Strength in Numbers: Why State Join Interstate Compacts". State Politics and Policy Quarterly 7(4):347-368.

Breitmeier, Helmut, Oran Young, and Michael Zorn. 2006. Analyzing International Environmental Regimes. Cambridge, MA: MIT Press.

Buchanan, James M., and Gordon Tullock. 1962. The Calculus of Consent, Logical Foundations of Constitutional Democracy. Ann Arbor: University of Michigan Press.

Carpenter, Delph. 1925. "South Platte River Compact Report of Delph E. Carpenter Commissioner of Colorado" Denver, Colorado, January 7, 1925.

Coase, Ronald. 1937. "The Nature of the Firm" Economica 4:386-405.

Coglianese, Cary. 1997. "Assessing Consensus: The promise and Performance of Negotiated Rulemaking" Duke Law Journal 46:1255-1337.

Coglianese, Cary.1999. "The Limits of Consensus" Environment 41(3):28-32.

Coglianese, Cary, and Laurie K. Allen. 2004. "Does Consensus Make Common Sense? An Analysis of EPA's Common Sense Initiative." Environment_46 11): 10-25.

Commons, John R. 1968. Legal Foundations of Capitalism. Madison, WI: University of Wisconsin Press.

Crawford, Sue and Elinor Ostrom. 1995. "A Grammar of Institutions" American Political Science Review 89(3): 5 82-600.

Derthick, Martha. 1974. Between State and Nation: Regional Organizations of the United States. Washington, DC: The Brookings Institution.

Dirk, Catherine L. 1978. "Federal Reserved Rights and the Interstate Allocation of Water." Land and Water Law Review 13: 813-833.

Dworsky, L. B., D. J. Allee, et al. 1991. "Water Resources Planning and Management in the United States Federal System: Long-Term Assessment and Intergovernmental Issues for the Nineties." Natural Resources Journal. 31 3(475-547).

Elazar, Daniel. 1987. Exploring Federalism. Tuscaloosa, AL: The University of Alabama Press.

Fearon, James. 1998. "Bargaining, Enforcement, and International Cooperation" International Organization 52(2) :269-305.

Featherstone, Jeffrey P. 1999. An evaluation of federal-interstate compacts as an institutional model for intergovernmental coordination and management: Water resources for interstate river basins in the United States. Ph.D. Dissertation, Temple University.

Florestano, Patricia S. 1994. "Past and Present Utilization of Interstate Compacts in the United States." Publius 24(4): 13-25.

Frazier, Derrick V. and William J. Dixon 2006. "Third Party Intermediaries and Negotiated Settlements, 1946-2000. International Interactions 32: 385-408.

Gaenslen, Fritz. 1996. "Motivational Orientation and the Nature of Consensual Decision Processes: A Triangulated Approach" Political Research Quarterly 49(1):27-49. 
Giardot, Joseph. W. 1989. "Toward a Rational Scheme of Interstate Water Compact Adjudication." University of Michigan Journal of Law Reform 22: 151-178.

Gilmore, V. 1987. Interstate Competition for Water: The Virginia Beach Case. Ph.D. Dissertation, The University of North Carolina, Chapel Hill.

Grant, Douglas. L. 2003. "Interstate Water Allocation Compacts: When the Virtue of Permanence Becomes the Vice of Inflexibility." University of Colorado Law Review 74: 105-180.

Gregory, Robin, Tim McDaniels, Daryl Fields. 2001. "Decision Aiding and Not Dispute Resolution: Creating Insights Through Structured Environmental Decisions" Journal of Policy Analysis and Management 20(3):415-432.

Gold, David H. 2002. "Supreme Court Struggles with Damage Assessment in Water Dispute as Interstate Compact Breaks Down" Ecology Law Quarterly 29(2): 427-431.

Haller, T. G. 1981. California-Nevada Interstate Water Compact A Study in Controversy. Ph.D. Dissertation, University of Nevada, Reno.

Hasday, Jill E. 1997. "Interstate Compacts in a Democratic Society: The Problem of Permanency." Florida Law Review. 49: 1-47.

Heikkila, Tanya, and Andrea Gerlak. 2005. "The Formation of Large-scale Collaborative Resource Management Institutions: Clarifying the Roles of Stakeholders, Science, and Institutions." Policy Studies Journal 33(4): 583-612.

Hill, James Perry. 1992. Managing the Nation's Waters Without Washington: The Interstate Compact Experience. Ph.D. Dissertation, Michigan State University.

Jones, Bryan and Frank Baumgartner. 2005. The Politics of Attention. The University of Chicago Press.

Kenney, Douglas S. et al. 2000. Arguing About Consensus: Examining the Case Against Western Watershed Initiatives and Other Collaborative Groups in Natural Resources Management. Research Report No. 23. Boulder, CO: University of Colorado Natural Resources Law Center

Knight, Jack. 1992. Institutions and Social Conflict. New York: Cambridge University Press.

Knox, Kenneth. 2001. "The La Plata River Compact: Administration of An Ephemeral River In The Arid Southwest" University of Denver Water Law Review 5:104-122.

Knox, Kenneth. 2003. "The Costilla Creek Compact" University of Denver Water Law Review 6:453-490.

Knox, Kenneth. 2004. The Allocation of Interstate Groundwater: Evaluation of the Republican River Compact as a Case Study. Ph.D. Dissertation, Colorado State University.

Koontz, Tomas M., Toddi A. Steelman, JoAnn Carmin, Katrina Smith Korfmacher, Cassandra Moseley, and Craig W. Thomas. 2004. Collaborative Environmental Management: What Roles for Government? Washington, DC: RFF Press

Lach, Denise, Helen Ingram, and Steve Rayner. 2006. "You Never Miss the Water 'Till the Well Runs Dry: Crisis and Creativity in California." In Clumsy Solutions for a Complex World, eds. Marco Verweij and Michael Thompson. Cambridge: Cambridge University Press.

Landre, Peter and Lester Travis. 1998. "Collaborative Watershed Management in the Finger Lakes Region, New York". Paper presented at the International Association for the Study of Common Property Biannual Meeting, Bloomington, Indiana http://www.indiana.edu/ iascp/FinaI/landre.pdf 
Layzer, Judith. 2008. Natural Experiments: Ecosystem Based Management and the Environment. Cambridge, MA: MIT Press

Leach, Richard, and Reading Sugg. 1959. The Administration of Interstate Compacts. Baton Rouge: Louisiana State University Press.

Leach, William D., and Paul Sabatier. 2005. "To Trust an Adversary: Integrating Rational and Psychological Models of Collaborative Policymaking." American Political Science Review 99(4): 491-503.

Leach, William D., and Paul Sabatier. 2006. "Are Trust and Social Capital the Keys to Success? Watershed Partnerships in California and Washington". In Swimming Upstream: Collaborative Approaches to Watershed Management, eds by Paul Sabatier, et al. Cambridge, MA: MIT Press, pp. 233-258.

Leach, William D., Neil Pelkey, and Paul Sabatier. 2002. "Stakeholder Partnerships as Collaborative Policy Making: Evaluation Criteria Applied to Watershed Management in California and Washington" Journal of Policy Analysis and Management 21(4):645-670.

Lubell, Mark, Mark Schneider, John Scholz, and Mihrye Mete. 2002. "Watershed Partnerships and the Emergence of Collective Action Institutions." American Journal of Political Science 46(1): 48-63.

Lubell, Mark, et al. 2006. "Conclusions and Recommendations". In Swimming Upstream: Collaborative Approaches to Watershed Management. Edited by Paul Sabatier, et al. Cambridge, MA: MIT Press, pp. 261-296.

Margerum, Richard. 2007. "Overcoming Locally Based Collaboration Constraints" Society and Natural Resources 20:135-152.

Miller, Charles. 1985. "Group Decision Making Under Majority and Unanimity Decision Rules" Social Psychology Quarterly 48(1):51-61.

Miller, Gary. 1993. Managerial Dilemmas. Cambridge: Cambridge University Press.

Mitchell, Sara McLaughlin, and Paul Hensel. 2007. "International Institutions and Compliance with Agreements." American Journal of Political Science 51(4): 721-737.

Muys, Jerome. 2004. "The Western States' Experience With Interstate Water Issues" Paper prepared for the panel "Lessons From the West", sponsored by American Bar Association Section of Environment, Energy, and Resources, at the conference "Eastern Water Resources: Law, Policy and Technology, Hollywood, Florida, May 6-7, 2004.

Muys, Jerome, George William Sherk, Marilyn O'Leary. 2007. "Utton Transboundary Resources Center Model Interstate Water Compact" Natural Resources Journal, 47: 18-115.

North, Douglass. 1981. Structure and Change in Economic History. New York: WW Norton.

Ostrom, Elinor. 1990. Governing the Commons. Cambridge: Cambridge University Press.

Ostrom, Elinor. 2000. "The Danger of Self-Evident Truths" PS: Political Science and Politics 33(1): 33-44.

Ostrom, Elinor. 2005. Understanding Institutional Diversity. Princeton University Press.

Ragin, Charles. 1987. The Comparative Method. Berkeley: University of California Press.

Ragin, Charles. 2000. Fuzzy Set Analysis. Chicago: University of Chicago Press.

Ragin, Charles et al. 2006. User's Guide to Fuzzy-Set/Qualitative Comparative Analysis, http://www.u.arizona.edu/ cragin/fsQCA/

Ragin, Charles. 2008. Redesigning Social Inquiry: Fuzzy Sets and Beyond. University of Chicago Press. 
Ragin, Charles. 2009. "Qualitative Comparative Analysis Using Fuzzy Sets (fsQCA)". In Configurational Comparative Methods, eds, Benoit Rihoux and Charles Ragin. Sage Publications.

Robbins, David W., and Dennis M. Montgomery. 2001. "The Arkansas River Compact." University of Denver Water Law Review 5:58-103.

Republican River Compact Commission. 1960. Annual Report.

Republican River Compact Commission. 1970. Annual Report.

Sabatier, Paul, Will Focht, Mark Lubell, Zev Trachtenberg, Arnold Vedlitz, and Marty Matlock. 2005. Swimming Upstream: Collaborative Approaches to Watershed Management. Cambridge, MA: MIT Press, pp. 3-22

Scharpf, Fritz. 1997. Games Real Actors Play. Boulder, CO: Westview Press.

Sherk, George W. 2005. "The Management of Interstate Water Conflicts in the 21st Century: Is it Time to Call Uncle?" New York University Environmental Law Journal 12(3): 764-827.

Skalaban, Andrew. 1993. "Policy Cooperation among the States: The Case of Interstate Banking Reform" American Journal of Political Science, 37 (2): 415-428.

Thomas, Craig. 2003. Bureaucratic Landscapes: Interagency Cooperation and the Preservation of Landscapes. Cambridge, MA: MIT Press.

Thursby, Vincent. 1953. Interstate Cooperation: A Study of the Interstate Compact. Washington Public Affairs Press.

Tsebelis, George. 1992. Nested Games: Rational Choice in Comparative Politics. Berkeley: University of California Press.

Weber, Edward P. 2003. Bringing Society Back In. Cambridge, MA: MIT Press

Weissert, Carol S., and Jeffery S. Hill. 1994. "Low-Level Radioactive Waste Compacts: Lessons Learned from Theory and Practice." Publius 24 (4): 27-43.

Williamson, Oliver. 1985. The Economic Institutions of Capitalism. New York: Free Press.

Young, Oran. 2002. "Institutional Interplay: The Environmental Consequences of Cross-scale Interactions" in The Drama of the Commons. Edited by Elinor Ostrom, Thomas Dietz, Nives Dolsak, Paul Stern, Susan Stonich and Elke U. Weber. Washington, DC: National Academy Press, pp.263-292

Zimmerman, Joseph F. 1994 Introduction: Dimensions of Interstate Relations. Publius 24( Autumn): 1-11.

Zimmerman, Joseph F. 2002. Interstate Cooperation: Compacts and Administrative Agreements. Westport, CT: Praeger.

Zimmerman, Frederick L., and Mitchell Wendell. 1951. The Interstate Compact Since 1925. Chicago Council of State Governments. 


\section{Appendix A}

The following explanation of qualitative comparative analysis (QCA) draws heavily from Ragin, Charles et al (2006) User's Guide to Fuzzy-Set/Qualitative Comparative Analysis, http://www.u.arizona.edu/ cragin/fsQCA/; particularly Part II - Crisp Set Analysis, pp. 10-19.

QCA is based on Boolean algebra, where a case is either in or out of a set; 1 indicates membership and 0 indicates nonmembership. Analysis begins with the construction of a truth table which consists of a series of rows. Each logical combination of values on the independent variables represents one row. Truth tables have as many rows as there are logically possible combinations of values on the independent variables. Table 2 is an abbreviated truth table for Model 1 and Table 3 is an abbreviated truth table for Model 2. Tables 2 and 3 only contain the logical combination of values on the independent variables that are present in the dataset (versus all potential logical combinations of conditions). The values of the variables of a row in a truth table are combined using Boolean multiplication, where * means AND. Thus, the appropriate interpretation of the first row of Table 2 is conflicts consisting of interstate parties AND distributional issues AND the absence of compatability issues AND the absence of upstream downstream issues, AND the absence of complexity are resolved by commissions. Thus, in Boolean based qualitative comparison, independent variables are not viewed in isolation but always within the context of the presence and absence of other relevant conditions.

Boolean algebra is used to reduce the number of rows in a truth table and groupings of independent variables to those that are necessary and/or sufficient for a particular outcome. In Boolean algebra terms, each row of a truth table is known as a primitive expression. The basic rule for reducing primitive expressions and formulating more succinct Boolean statements is if two Boolean expressions differ in only one condition but are associated with the same outcome then the condition may be removed to create a simpler, combined expression. For instance, in Table 2, row 1 and row 2 differ only on upstream/downstream. The two rows may be combined to form INTERSTATE PARTIES*DISTRIBUTIONAL*compatability*complexity. (Recall that upper case means the variable is present and lower case means the variable is absent). This process of logical minimization is conducted in a bottom-up fashion until no further stepwise reduction of Boolean expressions is possible. This basic rule of minimization seeks to identify simpler combinations of conditions for which is an outcome occurs. It is experiment like in its focus on pairs of configurations differing in only one variable.

Further reduction of configurations of variables is possible using a minimization device known as a prime implicant chart. Primitive expressions (that is rows of a truth table), when reduced using the basic rule, are known as prime implicants. Often there are more prime implicants than are needed to cover all the original primitive expressions. In order to determine which prime implicants are logically essential, a prime implicant chart is used. The goal of using a prime implicant chart is to "cover" as many of the primitive Boolean expressions as possible with a logically minimal number of prime implicants. The objective is to provide a parsimonious explanation. Both the basic minimization rule and a prime implicant chart were used to solve Model 1 and Model 2. Solutions were derived using QCA software, we did not manually derive them.

For further information on QCA, please consult Charles Ragin's website http://www.u.arizona.edu/ cragin/fsQCA/; or Charles Ragin (2008) Redesigning Social Inquiry: Fuzzy Sets and Beyond. University of Chicago Press 
Table 1. Overview of Interstate River Compacts and Conflicts Studied

\begin{tabular}{|c|c|c|c|c|}
\hline Compact & $\begin{array}{l}\text { Year } \\
\text { Signed }\end{array}$ & Member States & $\begin{array}{l}\text { Number of } \\
\text { compact-related } \\
\text { conflicts }\end{array}$ & $\begin{array}{l}\text { Compact-related } \\
\text { conflicts } \\
\text { addressed by } \\
\text { commissions }\end{array}$ \\
\hline Arkansas & 1949 & Colorado, Kansas & 5 & 2 \\
\hline Bear & $\begin{array}{l}1955 \\
1980\end{array}$ & Idaho, Utah, Wyoming & 7 & 4 \\
\hline Belle Fourche* & 1943 & South Dakota, Wyoming & 0 & $\mathbf{0}$ \\
\hline Big Blue & 1971 & Kansas, Nebraska & 0 & $\mathbf{0}$ \\
\hline Costilla Creek & $\begin{array}{l}1944, \\
1963\end{array}$ & Colorado, New Mexico & 1 & 1 \\
\hline Klamath (Upper) & 1956 & California, Oregon & 0 & $\mathbf{0}$ \\
\hline La-Plata* & 1922 & Colorado, New Mexico & 1 & $\mathbf{0}$ \\
\hline Pecos & 1949 & New Mexico, Texas & 1 & $\mathbf{0}$ \\
\hline Republican & 1943 & Colorado, Kansas, Nebraska & 1 & $\mathbf{0}$ \\
\hline Rio Grande & 1938 & $\begin{array}{l}\text { Colorado, New Mexico, } \\
\text { Texas }\end{array}$ & 3 & 1 \\
\hline Snake (Upper) & 1949 & Idaho, Utah, Wyoming & 1 & $\mathbf{0}$ \\
\hline South Platte* & 1923 & Colorado, Nebraska & 0 & $\mathbf{0}$ \\
\hline Upper Niobrara* & 1962 & Nebraska, Wyoming & 0 & $\mathbf{0}$ \\
\hline Yellowstone & 1950 & $\begin{array}{l}\text { Montana, Wyoming } \\
\text { (North Dakota, non-voting) }\end{array}$ & 3 & $\mathbf{0}$ \\
\hline
\end{tabular}


Table 2. Conflict Configurations Addressed by Compact Commissions ( $\mathrm{n}=\mathbf{8}$

\begin{tabular}{|c|c|c|c|c|c|c|}
\hline Configuration & $\begin{array}{l}\text { INTERSTATE } \\
\text { PARTIES }\end{array}$ & DISTRIBUTIONAL & COMPATIBILITY & $\begin{array}{l}\text { UPSTREAM } \\
\text { DOWNSTREAM }\end{array}$ & COMPLEXITY & Number of cases \\
\hline one & 1 & 1 & 0 & 0 & 0 & 3 \\
\hline two & 1 & 1 & 0 & 1 & 0 & 2 \\
\hline three & 1 & 0 & 1 & 0 & 0 & 1 \\
\hline four & 1 & 0 & 0 & 0 & 0 & 2 \\
\hline
\end{tabular}

$1=$ condition is present in case, $0=$ condition is absent in the case

Table 2 Explanation: Each row represents conflict cases that exhibit a specific configuration of conflict characteristics or conditions. For instance, configuration one, found in three cases, consists of conflicts that involve interstate parties and distributional issues. Overall, the table illustrates

that compact commissions address conflicts involving interstate parties and various combinations of other conditions, such as compatibility

conflicts between state law and compact requirements.

Table 3. Conflict Configurations Addressed by Alternative Venues $(n=15)$

\begin{tabular}{|c|l|l|l|l|l|l|}
\hline Configuration & $\begin{array}{l}\text { INTERSTATE } \\
\text { PARTIES }\end{array}$ & DISTRBUTIONAL & COMPATABILITY & $\begin{array}{l}\text { UPSTREAM } \\
\text { DOWNSTREAM }\end{array}$ & COMPLEXITY & Number of cases \\
\hline one & 0 & 1 & 1 & 0 & 0 & 1 \\
\hline two & 0 & 1 & 0 & 0 & 0 & 2 \\
\hline three & 0 & 0 & 1 & 0 & 0 & 2 \\
\hline four & 1 & 0 & 0 & 1 & 0 & 2 \\
\hline five & 1 & 0 & 1 & 1 & 0 & 1 \\
\hline six & 1 & 0 & 1 & 1 & 1 & 1 \\
\hline seven & 1 & 1 & 0 & 0 & 1 & 2 \\
\hline eight & 1 & 1 & 0 & 1 & 1 & 1 \\
\hline nine & 1 & 1 & 0 & 0 & 0 & 1 \\
\hline ten & 1 & 1 & 0 & 1 & 0 & 1 \\
\hline eleven & 1 & 0 & 1 & 0 & 0 & 1 \\
\hline
\end{tabular}

$=$ condition is present in case, $0=$ condition is absent in the case

Table 3 Explanation: Each row represents conflict cases that exhibit a specific configuration of conflict characteristics or conditions. For instance, row one consists of a conflict case addressed by a venue other than a compact commission that involved intrastate parties and distributional and

compatibility issues. Overall the table illustrates that venues other than compact commissions address a diverse set of conflict cases that exhibit a number of different combinations of issues. 
Table 4. Conflict Solutions by Venue

\begin{tabular}{|c|c|c|c|c|c|}
\hline \multirow[b]{2}{*}{ Conflict Solutions } & \multicolumn{4}{|c|}{ Venues of Final Decision (mutually exclusive) } & \multirow[b]{2}{*}{ Total } \\
\hline & Commission & Courts & $\begin{array}{l}\text { Federal or } \\
\text { State Agency }\end{array}$ & Legislature & \\
\hline Status Quo & 0 & 4 & 1 & 0 & $\begin{array}{l}5 \\
(22 \%)\end{array}$ \\
\hline Strategy Change & 0 & 0 & 2 & 0 & $\begin{array}{l}2 \\
(8 \%)\end{array}$ \\
\hline Operational Rule Change & 6 & 1 & 1 & 1 & $\begin{array}{l}9 \\
(39 \%)\end{array}$ \\
\hline $\begin{array}{l}\text { Collective Choice Rule } \\
\text { Change }\end{array}$ & 1 & 2 & 0 & 0 & $\begin{array}{l}3 \\
(13 \%) \\
\end{array}$ \\
\hline $\begin{array}{l}\text { Constitutional Choice } \\
\text { Rule Change }\end{array}$ & 1 & 3 & 0 & 0 & $\begin{array}{l}4 \\
(17 \%)\end{array}$ \\
\hline Total & $\begin{array}{l}8 \\
(35 \%)\end{array}$ & $\begin{array}{l}10 \\
(43 \%) \\
\end{array}$ & $\begin{array}{l}4 \\
(17 \%)\end{array}$ & $\begin{array}{l}1 \\
(4 \%)\end{array}$ & $\begin{array}{l}23 \\
(\mathbf{1 0 0 \%})\end{array}$ \\
\hline
\end{tabular}




\begin{tabular}{|c|c|c|}
\hline Solution: & $\begin{array}{l}\text { Solution } \\
\text { coverage }\end{array}$ & $\begin{array}{l}\text { Solution } \\
\text { consistency }\end{array}$ \\
\hline INTERSTATE*distributionaI*compatibility*upstream/downstream & 0.25 & 1.00 \\
\hline
\end{tabular}

Figure 1 Explanation: The solution identifies the sufficient conditions for a conflict case to be addressed by a compact commission and no other venue. Only conflict cases that exhibit interstate parties, but no distributional issues and no compatibility issues and no upstream/downstream issues are addressed exclusively by compact commissions. Of the eight conflicts addressed by commissions (see Table 2), two are of this type, the other types of conflict cases have been addressed by other venues as well as by commissions.

\begin{tabular}{|lcc|}
\hline $\begin{array}{c}\text { Figure 2: fs-QCA Solution for Conflicts Resolved } \\
\text { Minimized Solution }\end{array}$ & $\begin{array}{c}\text { Byternative Venues } \\
\text { Coverage }^{\mathrm{a}}\end{array}$ & Consistency \\
\cline { 2 - 3 } interstate parties + & 0.33 & 1.00 \\
distributional*UPSTREAM/DOWNSTREAM + & 0.27 & 1.00 \\
DISTRIBUTIONAL ${ }^{*}$ COMPLEXITY & 0.20 & 1.00 \\
solution consistency: 1.00 & & \\
Solution coverage 0.80 & & \\
\end{tabular}

${ }^{\mathrm{a}}$ The solution to Model 2 consists of three distinct configurations of conflict conditions that are addressed by venues other than commissions. Each solution accounts for a portion of the cases that are addressed by alternative venues. If a model has more than one solution, QCA generates two different coverage scores because solutions may overlap, that is, they may share one or more conditions. The unique coverage score measures the number of cases exhibiting a configuration of conditions that result in the outcome but that do not overlap with any of the other solutions. The raw coverage score measures the number of cases exhibiting a configuration of conditions that include overlap cases. A simple inspection of the three solutions to Model 2 indicates there is no overlap among them, that is, they do not share the presence or absence of a condition, thus the raw and unique coverage scores are identical. Consequently, we only report a single coverage score.

Figure 2 Explanation: The solution identifies the sufficient conditions for a conflict case to be addressed by a venue other than a compact commission. There are three solutions. First, conflicts that do not involve interstate parties are only addressed by alternative venues. Second, conflict cases that exhibit no distributional issues and upstream/downstream issues are only addressed by alternative venues. Third, conflict cases that exhibit distributional issues and are complex are only addressed by alternative venues. Twelve of the fifteen conflict cases addressed by alternative venues are covered by these three solutions or types of cases. Compared to commissions, alternative venues address more varied types of conflicts. 